\section{A CONTINUOUS CALORIMETER}

To the Editor of Science: In your issue of July 24 Professor Lyndley Pyle refers to the use of the continuous calorimeter by students of Washington University for the past fifteen years. It is gratifying to learn that the method has been so thoroughly tested elsewhere for this purpose. In taking up your valuable space in $\mathrm{my}$ article of May $15 \mathrm{I}$ described a particular type of simple calorimeter that we have found most suitable for the elemientary work. That this method is not generally used in place of the older and more troublesome method of measuring Joule's heat appears to be because sufficient attention has not been drawn to it. The directness, accuracy and ease of manipulation will appeal I think to all those who have charge of laboratory classes.

The method itself, is, of course, not new. Callendar used it more than twenty-two years ago at Cambridge for comparing the thermal and electrical units, but it was not until he came to McGill University in 1893 that steps were taken to thoroughly investigate the merits of the method. A continuous method was used by Graetz as early as 1882 for measuring thermal conductivities.

\section{H. T. Barnes}

McGill University, July 29, 1908

\section{SOIENTIFIC BOOKS}

Publications of the Jesup North Pacific Expedition. Edited by Franz Boas. Leiden, E. J. Brill Limited; New York, G. E. Stechert \& Co. 4to.

During the past year the following numbers of this publication have been issued:

The Lillooet Indians. By James TeIt. (Vol. II., Part V.)

In this book Mr. Teit describes the customs of the Lillooet, a branch of the Salish Indians, who inhabit the valleys of the Coast Range of British Columbia, from Harrison Lake to the upper reaches of Fraser River. Mr. Teit visited the tribe twice, and describes in some detail the customs of both its lower and upper divisions. The plan of description is similar to that of Mr. Teit's well-known book on the Thompson Indians of British Columbia; the habitat and divisions of the tribe, material culture, warfare, games and pastimes, social organization and festivals, birth, childhood, marriage and death, and religion being taken up in detail. On the whole, the Lillooet resemble in their culture the tribes of the interior, but they form an interesting link between them and the coast tribes, having adopted many of the industries and a considerable part of the social traits of the coast tribes. Mr. Teit describes in detail how the influence of the coast culture gradually diminishes towards those divisions of the Lillooet that reside farthest away from the coast. Of special interest in the descriptions is the discussion of the imbricated basketry and of the basketry designs of the tribe, a subject which has received considerable attention in recent literature. The houses of the division of the tribe living near the coast were similar in structure to the large wooden houses of the Coast Salish, while the tribes of the interior lived in underground dwellings and in tents. Weaving like that produced by the Salish Indians of the Gulf of Georgia was confined to the Lower Lillooet. The tribe has been so much influenced by the whites that very few of the old specimens remain, and consequently not many of the objects in use among them formerly could be illustrated. The transitional stage in the social organization of the tribe is interesting from a theoretical point of view, in so far as it shows clearly how a semi-totemic organization may influence a people that in previous times was organized only in very loose village communities. At the present time the influence of the totemic organization may be observed particularly in grave-monuments which are still preserved, many of which represent figures of ancestors and of totemic beings. The religious concepts of the people differ only slightly from those of the Thompson Indians. The numerous rockpaintings in the Lillooet country have reference particularly to the puberty ceremonials, and are explained in a manner similar to those 